\title{
The Role of Indonesian Language Learning in Shaping the Character of Students
}

\author{
Cecep Wahyu Hoerudin \\ UIN Sunan Gunung Djati Bandung, Indonesia \\ Email: cecepwahyu@uinsgd.ac.id
}

\begin{abstract}
The function of language, particularly Indonesian, in moulding the character of a student is critical, and this is true both orally and in writing. An Indonesian instructor must understand that learning the language is about developing language skills rather than mastering the grammar of the language. Because of this, this study emphasized the issue of improving the competence of Indonesian language teachers so that they can better serve their students. In order to uncover the subject of inquiry, this study employs a qualitative technique combined with descriptive methodologies. According to the findings of the study, learning the Indonesian language has a major impact on the development of students' personalities and character. It is possible to receive assistance by learning to read and write as well as speak and listen.
\end{abstract}

Keywords: Competence, Indonesian Language Teacher, Teacher Welfare.

\section{A. INTRODUCTION}

The millennial era is a momentum marked by massive changes in almost all aspects of life. These various changes are like two blades of a knife, which can bring benefits in life, but at the same time, can cause chaos if not addressed in a good way (Gustry et al., 2020). Character education is one of the efforts to answer the various humanitarian challenges posed by such massive technological developments so that humans (students) can respond appropriately to technological developments. Through a well-packaged learning process, including the preparation of evaluation tools, it is hoped that students can become superior individuals, both in terms of cognitive, affective, and psychomotor (Syamsuar \& Reflianto, 2019).

As Gunawan (2012) points out, each individual's character can be regarded as a distinct way of thinking and behaving that allows them to live and work together in the context of the family, community, country, and state. Individuals with good character, according to him, are capable of making decisions and are willing to accept responsibility for any consequences of those decisions. As an additional point of contention, he asserts that character can be defined as the values of human behavior that are related to God Almighty, one's own self, one's fellow humans, the environment, and nationality and that are manifested in thoughts, attitudes, feelings, words, and actions that are based on religious standards. These values include those related to God Almighty, one's own self, one's fellow humans, and the environment.

According to Mulyasa (2011), character education has a greater significance than moral education because character education is not only concerned with the problem of right and wrong but also with how to instill habits (habits) about good 
things in life so that children or students have awareness and a high understanding of virtue as well as concern and commitment to apply virtue in everyday life, as opposed to moral education. The curriculum states that one of the core competencies in Indonesian language learning is that students are able to appreciate and live honest behavior; discipline; responsibility; caring (tolerance; cooperation); polite; confident; in interacting effectively with the social and natural environment; in interacting effectively with the social and natural environment; in interacting effectively with the social and natural environment; in interacting effectively with the social and natural environment (Pantu \& Luneto, 2014).

Indonesian is the national language and the state language. As a national language, it functions as a symbol of national pride, a unifying tool for various ethnic groups with socio-cultural and linguistic backgrounds, cultural developers, science and technology developers, and communication tools in the interests of government and state (Hidayah, 2015). As a state language, it functions as the language of instruction in educational institutions, as a developer of culture, as a developer of science and technology, and as a means of government and state communication.

Given the position and function of the Indonesian language, the role of education greatly determines its implementation, especially in learning Indonesian, which is taught to students. In this case, the teacher in the performance of learning should be aware that there is an installation of character values in students in language learning. Students will know that the language they use reflects the noble sociocultural values of the Indonesian nation (Wijaya et al., 2017. Using Indonesian, we can understand our temperament, nature, and character as users. For that, we must guard against it. Our personality does not reflect the noble values of the Indonesian nation (Badawi, 2020).

One of the goals that must be achieved through the implementation of Indonesian language learning is that students can use Indonesian to improve intellectual abilities and emotional and social maturity. This goal implies that learning Indonesian is not merely to achieve language skills but further, namely through language skills, mature students must be formed, both cognitively, socially, and emotionally (Lestyarini, 2012). In other words, Indonesian language learning must be packaged in such a way as to build students as a whole and with character. Language does reflect a person's character. Therefore, it is appropriate that learning Indonesian is one of the vehicles that can build a strong student character, both in the intellectual, social, and emotional dimensions (Widaningsih, 2019).

Based on the description above, the problem in this research is the role of learning Indonesian in shaping students' character. This study tries to describe what is stated in this article.

\section{B. METHOD}

The method used in this study is a qualitative descriptive method through theoretical analysis. This method is used to understand a phenomenon related to the background of the research subject in depth (Moleong, 2011). This study uses a 
literature review from various library data sources by analyzing, describing, and concluding according to the research objectives. Researchers used descriptive methods because the data collected were words, pictures, and not numbers, so the research report will contain data to provide an overview of the presentation of the information.

\section{RESULT AND DISCUSSION}

\section{Character Education}

Character education is an effort to develop and educate one's character, namely psychological, moral, and character, to improve it. Character education teaches character values to school members, which includes components of knowledge, awareness or willingness, and actions to implement character values. Character education is essentially aimed at forming a strong, competitive, noble, moral, tolerant, cooperative, patriotic, dynamically developing, oriented to science and technology, all of which are imbued with faith and piety to God Almighty based on Pancasila (Citra, 2007). 2012). Furthermore, the Ministry of National Education (2010) states that character in educational theory is if a person has cognitive, affective, and psychomotor potential that is actualized in his life. Based on social theory, someone with character has logic and sense in establishing intrapersonal and interpersonal relationships in social life.

Character education functions to develop the essential potential to be kind, think well, behave well, strengthen and build the behavior of a multicultural nation, and improve the nation's competitive civilization in world relations. Character education is carried out through various media, including families, education units, civil society, political communities, government, business world, and mass media. The goal is to instill and shape the nature or character obtained from trials, sacrifices, life experiences, and values invested in forming intrinsic values that will become the attitudes and behavior of students. The weights that are ingrained in the form of attitudes and behavior are given continuously to form a habit. And these habits will be unique character for individuals or groups (Edison, 2019).

A person's character reveals how he or she acts. A person is considered to exhibit awful behavior if they act dishonestly, ruthlessly, and greedily. The opposite is also true: if someone acts honestly, responsibly, and genuinely enjoys helping others, that individual has a noble disposition. Character can be thought of as a subset of personality. There's no such thing as a "person of character" who doesn't adhere to ethical standards. Consequently, good character education must include not just features of moral knowing but also aspects of moral feeling and righteous conduct (righteousness). " (Julaiha, 2014).

Because character education is an educational process that develops ideals, attitudes, and behaviors that reflect noble character, it is regarded very vital to begin at an early age. People who exhibit noble character are expected to be pious in their actions, trustworthy, anticipatory of others' needs and desires, hard-working, civilized and brave in their pursuit of justice, disciplined, broad-hearted and soft- 
hearted, faithful., initiative, strong-willed personality, unpretentiousness, passion and constructive, grateful, responsible and tolerant, wise, intelligent, careful, democratic and dynamic. empathic. As of 2017, (Suwartini, 2017).

Character education or manners is very effectively applied to formal education. Character education in schools does not have to develop a new curriculum; character education can be included in the main points of discussion. Give advice, direction, instructions to do good. On the other hand, not doing something terrible before and after delivering the material or on the sidelines of providing the material is a way to educate the character of students.

Efforts to instill a sense of national identity in children at a young age are seen to be a positive step. Character education has been incorporated into the structure and content of the Education Unit Level Curriculum as of the 2010/2011 academic year (KTSP). A concept of character education is formed in each school according to how it is integrated into the curriculum of their particular schools. The Competency-Based Curriculum (KBK), which was later applied to the Education Unit Level Curriculum (KTSP), is a curriculum designed to provide the most comprehensive opportunity for schools and educators to carry out educational practices to develop all of the potential of students, both through the learning process in the classroom and through selfdevelopment programs. The Competency-Based Curriculum (KBK), which was later applied to the Education Unit Level Curriculum (KTSP), is a curriculum designed to provide the most comprehensive opportunity for schools and educators to carry out educational practices to (extracurricular).

Teachers hold a critical position in the development of students' character in schools, serving as the primary actor in this process. The instructor is a role model who can inspire students to emulate him or her or perhaps become their hero. It is possible for teachers to serve as a source of inspiration and motivation to their students. Students' views and behaviors are strongly imprinted by their teachers, to the point that the teacher's voice, character, and personality become a reflection of the students' own. As a result, instructors bear a significant amount of responsibility in developing a generation of character, culture, and morals. Human tasks include transformation, identification, and comprehension of oneself, all of which must be carried out in concert as an organic, harmonious, and dynamic unit in order for them to be completed successfully.

\section{The Role of Indonesian Language Learning in Character Building Students}

The following describes the role of Indonesian Language Learning in the formation of students' character, which includes:

a. Character building through listening learning

Listening is one of the receptive language skills, which means that listening must understand what is contained in the material being listened to. Listening can be interpreted as an active activity that is carried out seriously to understand the message in the material heard orally. Listening learning is conceptualized as a series of activities carried out by students to achieve particular learning outcomes in the 
guidance, direction, and motivation of a teacher. Thus, listening learning is a series of activities carried out by students to obtain and understand messages, information, and a series of ideas contained in the material through the guidance of the teacher's direction and motivation.

This listening learning procedure is a channel for character education concerning character education. At each stage of listening learning, there will be several activities that students must do. Through these activities, students will unconsciously show their character. At the pre-listening stage, students can carry out a series of activities, such as brainstorming about general things that may be contained in the material they are listening to. When students explore their schemata, they are getting used to, to be honest, that is, saying things they already know and not saying things they don't know. Besides being honest, the character values in this activity are attention, courage, and self-confidence. Another alternative to what is done at the prereading session, students must learn various visualizations related to the listening material. At that time, students will develop the character values of discipline, hard work, curiosity, and analysis. In other activities, such as making predictions, students are required to develop the character values of attention, commitment, creativity, sensitivity, and self-control.

Students can carry out listening activities by filling out concept maps at the listening stage. This activity will form thorough, careful, have a high work ethic, and are disciplined. Another exercise is to record the main ideas that have implications for developing dynamic, detailed, and productive characters. When students listen intensively to the text to build their understanding of the material, they will form hard-working, disciplined, and tenacious characters in students. If a series of activities at the listening stage is carried out in groups, the values of gotong royong, tolerance, democracy, and responsibility will be formed. Various characters will also be developed at the post-listening stage, such as being honest in answering questions, being creative in changing the content of the material into other discourses, and being brave in expressing the results of their understanding of a result listening. Apart from this activity, of course, many other post-listening activities will shape students' character depending on the method used.

b. Character Building through Learning to Talk

Speaking skill occupies an essential position because it is a characteristic of students' communicative abilities. In other words, speaking skills play a role in language learning and play an indispensable role in additional learning. This means that one indicator of the success of students' learning is their ability to express their ideas orally in class in a particular subject area. Speaking is very closely related to the activity of producing pictures. The belief in question is the thoughts produced by the speaker based on various known sources. Ideas can come from observation, experience, and imagination. The speaker's brain carefully processes stimuli from multiple sources by involving all components of his ability to think and even imagine. The results of this processing are then conveyed orally to other people. 
Concerning character education, the procedure for learning to speak goes through three stages, namely the pre-speaking, speaking, and post-speaking stages. At the pre-speak stage, students can carry out activities such as exploring phenomena to get ideas. This activity will require students to utilize their five senses and feelings in capturing inspiration or basic concepts for the material they are talking about. When students carry out exploration activities, they are getting used to being thorough, careful, sensitive, enthusiastic, responsible, and disciplined. Likewise, at the training stage, students must develop a serious, result-oriented, and creative character.

Students will build the character values of discipline, leadership, earnestness, achievement-oriented, polite, and courteous at the speaking stage. This is because the speaking process will require the ability to exchange roles, turn to speak so that it requires concentration and sincerity from the actors. In giving speeches, students are also required to dress politely, talk politely, and have an ethical style. Likewise, in scientific oration activities or debates, students will be accustomed to respecting others, caring, and being responsible. Based on this fact, it is clear that if the activities at the speaking stage are carried out correctly, students will acquire the ability to speak and at the same time will acquire character development so that in the end, the positive character will be entrenched in students.

At the post-talk stage, question and answer activities can be carried out, which can be used as a channel to cultivate character, especially the values of honesty, curiosity, caring, and achievement-oriented. In discussion activities, performance, and performance corrections, the importance of humble, open, honest, ethical, and scientific character will be cultivated. Likewise, the essence of responsibility, discipline, and work ethic will be developed at the performance development stage. Based on the description above, learning to speak can be used as a vehicle for implementing character education. The condition is that learning to say must be done actively and creatively so that students gain knowledge, experience, and character development so that Indonesian language learning is of quality and dignity.

c. Character Building through Learning to Read

Learning to read can be interpreted as a series of activities carried out by students to achieve reading skills under teachers' direction, guidance, and motivation. Learning to read is not only done so that students can read but a process that involves all visual and cognitive activities of students in understanding critiquing, and even producing a reading. In learning reading comprehension, for example, students are expected to understand the content of the assignment. Students should carry out a series of activities that can support learning objectives. Through these activities, students will unconsciously show their character.

At the pre-reading stage, students can carry out a series of activities such as brainstorming, general ideas that may be contained in the text. This activity will require students to express all the knowledge they already have to make it easier for them to understand the discourse. When students explore their schemata, they are getting used to, to be honest, that is, saying things they already know and not saying 
things they don't know. Apart from being honest, the character values in this activity are attention, courage, and self-confidence.

At the reading stage, students can carry out text reading activities at a glance through skimming and scanning reading activities. This activity will form thorough, careful, have a high work ethic, and are disciplined. Another activity that children can do is find the essence of reading which has implications for the formation of dynamic, careful, and productive characters. When children read the text intensively to build their understanding of the reading contents, they will form a hard-working, disciplined, and tenacious character in the child. If a series of reading activities are carried out in groups (cooperative), the values of gotong royong, tolerance, democracy, creativity, mutual respect, cooperation, and responsibility will also be formed.

At the post-reading stage, various characters will also be formed, for example, being honest in answering questions, being creative in changing the content of reading into other discourses, and being brave in expressing the results of their understanding of a reading.

d. Character Building through Writing Learning

Concerning character education, at each stage of learning to write, there are several activities that students must do. Through these activities, students will unconsciously show their character.

In the pre-writing stage, students will carry out activities such as exploring phenomena to get ideas. This activity will require students to utilize their five senses and feelings in capturing inspiration or basic ideas for their writing materials. When students do exploration, they are getting used to being thorough, sensitive, enthusiastic, responsible, creative, critical, initiative, and disciplined. When students write scripts cooperatively, students will be accustomed to mutual respect, cooperation, responsibility, creativity, critical, initiative, problem-solving, productivity, tenacity, skill, dare to take risks, commitment, and several other character values.

Students will be accustomed to being disciplined, honest, thorough, analytical, visionary, responsible, attentive, earnest, achievement-oriented, commitment, openness, neatness, firmness, prudence, flexibility, enthusiasm, work at the editing and reading stages hard, and so on.

Character values will develop at the publication stage, including selfconfidence, pride in themselves and their group, creativity, courage, discipline, sportsmanship, and trustworthiness (Abidin, 2015:197). Thus, learning to write can be used as a vehicle for implementing character education. Through the activities carried out, students will gain knowledge, experience, and character development.

Based on the description of the four language skills above, Satinem \& Achmad (2015) also suggests that "I hope that through Indonesian as a unified language, which can be seen from the way of speaking in communication, it can improve character 
education. Thus, character education delivered through Indonesian language learning as a communication tool can help students find their true identity and identity.

\section{CONCLUSION}

Character education must be instilled early during a fast-paced world development marked by rapid technological developments. Indonesian as the national language is a tool of national pride and unifying the nation. Therefore, teachers in the implementation of learning should be aware of that in learning. In this study, the role of Indonesian language learning in shaping the character of students can be seen from the character formation of listening learning, reading learning, speaking, and writing education.

\section{REFERENCES}

1. Badawi, B. (2020). Penanaman Nilai-Nilai Karakter dalam Fenomena Sosiolinguistik di Sekolah Dasar. JOEAI: Journal of Education and Instruction, 3(2), 305-311.

2. Citra, Y. (2012). Pelaksanaan Pendidikan Karakter dalam Pembelajaran. Jurnal Ilmiah Pendidikan Khusus, 1(1), 237-249.

3. Edison, E. (2019). Pendidikan Karakter dan Implementasinya. JOEAI: Journal of Education and Instruction, 2(2), 66-82.

4. Gunawan, H. (2012). Pendidikan karakter. Bandung: Alfabeta, 2(1).

5. Gusty, S., Nurmiati, N., Muliana, M., Sulaiman, O. K., Ginantra, N. L. W. S. R., Manuhutu, M. A., ... \& Warella, S. Y. (2020). Belajar Mandiri: Pembelajaran Daring di Tengah Pandemi Covid-19. Yayasan Kita Menulis.

6. Hidayah, N. (2015). Penanaman Nilai-Nilai Karakter dalam Pembelajaran Bahasa Indonesia di Sekolah Dasar. TERAMPIL: Jurnal Pendidikan dan Pembelajaran Dasar, 2(2), 190-204.

7. Julaiha, S. (2014). Implementasi Pendidikan Karakter Dalam Pembelajaran. Dinamika Ilmu: Jurnal Pendidikan, 14(2), 226-239.

8. Kemendiknas. (2010). Desain Induk Pendidikan Karakter. Jakarta: Kementerian Pendidikan Nasional.

9. Lestyarini, B. (2012). Penumbuhan Semangat Kebangsaan Untuk Memperkuat Karakter Indonesia Melalui Pembelajaran Bahasa. Jurnal Pendidikan Karakter, (3).

10. Moleong, J. (2011). Metodologi Penelitian Kualitatif. Bandung: Remaja Rosda Karya.

11. Mulyasa. (2011). Manajemen Pendidikan Karakter. Jakarta: Bumi Aksara.

12. Pantu, A., \& Luneto, B. (2014). Pendidikan Karakter dan Bahasa. Al-Ulum, 14(1), 153-170.

13. Satinem, S., \& Achmad, H. P. (2015). Teaching Materials Model Folklore in Learning Indonesian Based on Thematik Approach. IJLECR-International Journal of Language Education and Culture Review, 1(2), 27-34.

14. Suwartini, S. (2017). Pendidikan Karakter Dan Pembangunan Sumber Daya Manusia Keberlanjutan. Trihayu: Jurnal Pendidikan Ke-SD-an, 4(1). 
15. Syamsuar, S., \& Reflianto, R. (2019). Pendidikan dan tantangan pembelajaran berbasis teknologi informasi di era revolusi industri 4.0. E-Tech: Jurnal Ilmiah Teknologi Pendidikan, 6(2).

16. Widaningsih, I. (2019). Strategi dan Inovasi Pembelajaran Bahasa Indonesia di Era Revolusi Industri 4.0. Uwais Inspirasi Indonesia.

17. Wijaya, R., Sari, R. P., \& Murniati, S. (2017). Integrasi Pendidikan Karakter Dalam Pembelajaran Bahasa Indonesia. In Prosiding Seminar Nasional Program Pascasarjana Universitas PGRI Palembang. 